\title{
KARAHANLI TÜRKÇESİ DÖNEMİ KUR'AN TERCÜMELERİNDEN RYLANDS NÜSHASINDA FARSÇA TERCÜME ETKİSİ ÜZERINE MÜLAHAZALAR
}

\section{Yaşar ŞiMŞEK*}

\section{Öz}

Türkçe ile İranî diller arasındaki ilişki çok eski yüzyıllara kadar gitmektedir. Bu ilişki, Türklerin İslamiyet'i kabul etmeye başladıkları X-XI. yüzyıllarda daha da artmış, Türklerin İslamiyet'i anlamaları ve hayatlarının bir parçası hâline getirmeleri noktasında Fars kültürü Türk dinî muhitine ve Türk diline az veya çok tesir etmiştir. Bu tesir Türkçeye yapılan ilk Kur'an tercümelerinde de görülmektedir. Ancak konu üzerinde ne yazık ki yeterince durulmamıştır. $\mathrm{Bu}$ sebeple Karahanlı Dönemi Kur'an tercümelerinden Rylands nüshasında daha önce kısmen üzerinde durulan Farsça - Türkçe tercüme ilişkisi incelemeye alınmıştır.

İncelemede verilen örnekler bir makalenin hacmi gereği sinırlandırılmıştır. Ancak bu örneklerden hareketle dahi Türkçe tercümenin, Farsça tercümenin tercümesi olabileceği sonucuna ulaşılmıştır.

\section{Anahtar Sözcükler: Karahanlı Türkçesi, Kur'an tercümesi, Rylands nüshası. \\ IDEAS ABOUT THE PERSIAN TRANSLATION EFFECT IN THE RYLANDS MANUSCRPIT FROM THE QARAKHANID TURKISH QUR'AN}

\begin{abstract}
The relationship between the Turkish and the Persian languages dates back to very old centuries. This relationship became stronger in the $10^{\text {th }}$ and $11^{\text {th }}$ centuries when the Turks started to accept Islam, and the Persian culture had an impact on the Turkish religion neighborhood and the Turkish language in terms of the way they understand the Islam and making it a part of their lives to some extent. This impact has been seen in the first Turkish Qur'an translations as well. However, the topic hasn't been emphasized sufficently. Therefore, Persian-Turkish translation relationship which was discussed partially in the Rylands manuscrpit from the Qarakhanid period Qur'an translation has been examined.

The examples which were given in the study have been restricted by taking the volume of the article into consideration. However, it is easily thought that Turkish translation is the translation of the Persian translation when these examples are reviewed.
\end{abstract}

Keywords: Qarakhanid Turkish, Qur'an translation, Rylands manuscrpit.

\section{Ø. Giriş:}

Çin kaynaklarına göre $M O ̈$ II. yüzyıldan beri Çin ve Batı arasındaki İpek Yolu'nun rotasında bulunan Soğdlar, Amu Derya ve Sir Derya nehirleri arasında kalan İslam dünyasında

\footnotetext{
*Arş. Gör.; Kırıkkale Üniversitesi Fen Edebiyat Fakültesi Türk Dili ve Edebiyatı Bölümü, ysimsek55@ gmail.com.
} 
Maveraünnehir adıyla anılan coğrafyanın kadim tacirlerindendi. ${ }^{1}$ Bu bölge uzun yıllar Türk ve Karahanlı devletlerinin kontrolünde kalmış, Buhara, Semerkant, Kaşgar, Merv gibi kültür merkezlerinin gelişmesiyle sadece Soğdlara değil pek çok Türk kavmine de ev sahipliği yapmıştır. Bölge bugün Kazakistan, Özbekistan ve Türkmenistan arasında bölünmüş olsa da tarihin derinliklerinden getirdiği kültür havzası birikimini hâlâ korumaktadır.

Antik Türkistan'ın tüccar ve diplomat kavmi, dinî hoşgörüleri ve entelektüel birikimleri ile temayüz eden, ekonomik konuları politikaya tercih eden, ticareti savaştan daha yararlı gören, ilk yazılı belgeleri IV. yüzyıla ait olan Soğdlar, en eski dönemlerden itibaren Avrasya coğrafyasında, Çin'in Taşkurgan bölgesinden, İndus nehri boyunca Atlas Okyanusu'na, Akdeniz’e ve Kırım'a değin İpek Yolu üzerindeki kolonileri ve kervanlarıyla yalnızca ipek ve baharat değil, kelimeleri de taşımış, İpek Yolu'nun genel geçer dili Soğdca, kültürleri birbirleriyle âdeta harmanlamışt1 ${ }^{2}$.

Bölgede yaşayan Soğdlar ve Türkler arasındaki ilişkinin oldukça geriye gittiği bir sır değildir. Sakaların en yakın yerleşik komşusu, Buhara, Semerkant vahaları ile belki Fergana Vadisi'nde ve buna bitişik diğer bölgelerde yerleşmiş olan Soğdlardı. Soğdlar, bölgeleri Araplar tarafından fethedilinceye kadar, Semerkant'ın da içinde bulunduğu bir dizi küçük kent devleti hâlinde varlıklarını sürdürdüler. ${ }^{3}$

Soğdlar ile Türkler arasındaki ilişkiler, Soğdların Manihaizm'in Türkistan'daki misyonerliğini yapmış olmaları, Manihaizm'i Türkler arasında yaymış olmaları ile de doğrudan alakalıdır. III. yüzyılda Mani tarafından eski İran'da kurulan bu din, Türkistan'a, Hindistan'a hatta Avrupa'ya Soğdların misyonerlik faaliyetleri ile ulaşmıştı. Soğdların Doğu Türkistan'da ve Maveraünnehir bölgesinde eskiden beri meskûn oldukları bilindiğine göre Türk - Soğd ilişkileri sadece ticari ilişkilerle sınırlı kalmamış, dil, din, kültür alışverişi Köktürk Dönemi’nden önce başlamış olmalıdır. ${ }^{4}$

Türkistan bölgesinin Hun ve Türk devletleri tarafindan idare edilmeye başlamasıyla bölgede yaşayan Soğdların Türk devletlerinin çatısı altında varlıklarını sürdürdükleri ve Türklerle ilişkilerini yoğunlaştırdıkları düşünülebilir. İlişskinin boyutunu anlatan en güzel örnek

\footnotetext{
${ }^{1}$ Süer Eker, Orta Asya'nın Gizemli Halkı: Soğdlular Soğd ve Soğdca, Türkbilig, 2012/24, s. 77-92.

${ }^{2}$ Süer Eker, Divanü Lügati’t-Türk ve İran Dillerinden Kopyalar Üzerine I, International Journal of Central Asian Studies, Vol. 13, 2009, s. 237.

${ }^{3}$ A. K. Narain, İç Asya'da Hint-Avrupalılar, Erken İç Asya Tarihi, İletişim Yayınları, İstanbul, 2009, s. 242.

${ }^{4}$ bk. Selim Karakaş, Türk Tarihinde Maniheizm (VIII.-XIII. Yüzyıllar), Hacettepe Üniversitesi Sosyal Bilimler Enstitüsü Tarih Anabilim Dalı (doktora tezi), Ankara, 2010, s. 51-83.
} 
I. Türk Kağanlığı Dönemi’ne ait üç yüzü Soğdca bir yüzü Sanskritçe olan Bugut Yazıtı'dır. VI. yüzyılda bir Türk kağanı tarafından yaptırılan bu yazıt, Soğdların ve Soğdcanın Türkler arasında çok mühim bir mertebede bulunduğunun kanıtı durumundadır ${ }^{5}$. Bu ilişkinin iki taraflı çıkar ilişkisine dayandığını tahmin edebiliriz. Soğdlar, ticaretteki üstün meziyetleriyle ülkedeki ekonomik ilişkileri düzenliyor, Türkler de Soğdlardan istifade ederken onların dillerine statü kazandırıyordu. Statünün boyutu zamanla Soğdların devlet erkânında boy göstermelerine kadar ilerlemişti. ${ }^{6}$

S. Eker, İran dilleri ve Türkçe arasındaki ilişkinin 1. Eski Persçe ve birinci fetret dönemindeki iliş̧kiler, 2. Sasani Dönemi’ndeki ilişkiler, 3. Arap-İslam fütuhatını izleyen ikinci fetret dönemindeki ilişkiler, 4. İslamlaşan İran ve Farsçalaşan Persçeyle ilişkiler şeklinde dört ana dönemde incelenebileceğini belirtmektedir. ${ }^{7}$ 1. dönem $M O ̈$ VI - IV.; 2. dönem $M S$ III-VI.; 3. dönem $M S$ VII-IX. yüzyıllar arasını; 4. dönem daha sonraki evreleri kapsamaktadır. Burada bizi ilgilendiren, son dönem, yani Türk kavimlerinin büyük çoğunluğunun İslamiyet'e geçmeye başladıkları dönemdir. Orta Farsça olarak adlandırılan Soğdca döneminden sonra Türkçe ve İranî diller arasındaki ilişki İslamiyet'in yükselişi ile farklı bir boyut kazanmış, artık Türkler, Müslüman olan Farslarla ilişkilerini ticaretin ötesine götürmeye; bu ilişki neticesinde ve Orta Asya'da yayılmaya başlayan yeni dinin etkisi ile dinî terimler değişmeye başlamış, dinî terimlerde görülen değişimden başka, dinin algılanması ve uygulanması bakımından Fars kültürü Türk dinî muhitine ve Türk diline az veya çok tesir etmiştir. Bu tesirin tek taraflı olmadığı da aşikârdır. ${ }^{8}$ Kaşgarlının, Balasagunluların, Tıraz (Talas) ve Beyza şehirleri halkının Soğdca ve Türkçe kullandıklarını, Balasagun'a varıncaya kadar İspicab halkının dilinin çapraşık olduğunu belirtmesinden bölgede yaşayan Soğdların en azından bir bölümünün uzun soluklu yoğun temasların ardından Türkleştiğini anlıyoruz. ${ }^{9}$

Türkistan'da yaşayan Türkler Müslüman olmaya başladıklarında, Arap fütuhatı hızlanmış, İran çoktan İslamiyet ile tanışmıştı. İran'ın ve Türkistan'ın gezgin halkı Soğdlar (bu

\footnotetext{
${ }^{5}$ bk. Cengiz Alyılmaz, Bugut Yazıtı ve Anıt Mezar Külliyesi Üzerine, Türkiyat Araştırmaları Dergisi, S. 13, 2003 , s. 11-21.

${ }^{6}$ bk. Colin Mackerras, Uygurlar, Erken İç Asya Tarihi, İletişim Yayınları, İstanbul, 2009, s. 435.

${ }^{7}$ Süer Eker, Orhon Yazıtları: İran Dilleri İle İlk Temaslar ve Benzer Birkaç Öge Üzerine, III. Uluslararası Türkiyat Araştırmaları Sempozyumu, 2010, 1. Cilt, s. 322.

${ }^{8}$ bk. G. Doerfer, Türkische und Mongolische Elemente im Neupersischen, Wiesbaden, 1967.

${ }^{9}$ Süer Eker, Türk-İran Dil İlişkilerinde Divanü Lügati’t-Türk Tanıklığı, Akademik Araştırmalar Dergisi, 2008-2009, S. 39, s. 73 .

Araştırmacılar en azından bir kısım Soğdların Türkleştiği noktasında hem fikirdir.

bk. Z. V. Togan, Umumî Türk Tarihine Giriş, Enderun Kitabevi, İstanbul, 1981, s. 52-53.

bk. Jean-Paul Roux, Türklerin Tarihi, Kabalcı Yayınları, İstanbul, 2008, s. 83.

bk. V. V. Barthold, Orta Asya Türk Tarihi, Divan Kitap, Ankara, 2011, s. 93.
} 
dönemden sonra Fars olarak adlandırıldılar ve dilleri de değişmeye başladı), ticaretlerini artık inançlı birer Müslüman olarak gerçekleştirirken uzun yıllardır yaptıkları kültür taşıyıcılığını bu defa İslam adına yapmaya başlamış olabilirler miydi? Türkler, İslamiyet'i öğrenme aşamasında iken kendilerine Araplardan daha yakın gördükleri, uzun yıllar aynı coğrafyayı paylaştıkları bu halktan ne kadar etkilenmiş olabilirler? Kur'an'1 anlama, öğrenme ve hayatlarının bir parçası hâline getirme aşamasında Fars dinî çevreleri Türk dinî muhitini ne derece etkilemiş olabilir? Etkileşimin az veya çok kaçınılmaz olduğu gerçeği malum olmakla birlikte, Türkler, kutsal kitap Kur'an'1, kendi dillerine aktarırken İslamiyet ile daha önce tanışmış olan Farsların bu işte bir payı olmuş mudur?

$\mathrm{Bu}$ soruların cevaplanması için Türkçe ilk Kur'an tercümelerinin değerlendirilmesi konuya farklı bakış açılarının geliştirilmesinde katkı sağlayabilir. $\mathrm{Bu}$ sebeple, yazımızda Karahanlı Türkçesi Kur'an tercümelerinden Rylands Nüshası olarak bilinen Manchester, Rylands Kitaplığı Arapça Yazmalar bölümünde 25-38 numara ile kayıtlı olan nüshadaki Kur'an kavramlarının Farsça - Türkçe karşılıklarını karşılaştırmaya aldık. Elbette burada verilen örnekler, bir makalenin hacmini aşmamak üzere sınırlandırıldı. Kur'an kavramları için kullanacağımız eski sözlüklerin genellikle tefsir usulüne göre hazırlanmış olması, işimizi zorlaştıran en büyük etken idi. Kur'an'daki kavramların anlamları için Kitabu'l-'Ayn başta olmak üzere VIII. yüzyıldan itibaren Arap âlimleri tarafindan hazırlanan pek çok sözlük kullanılabilirdi, fakat biz Karahanlı Dönemi'nde İsfahanlı bir Arap tarafından yazılan Müfredāt adlı Kur'an kavramları sözlüğünü kullanmayı Rylands nüshasının yazıldığı döneme denk düşmesi sebebiyle uygun gördük. ${ }^{10}$

Tanıtım yazıları hariç tutulursa, Rylands nüshası üzerinde yeterince durulmadığı görülür. ${ }^{11}$ Nüshanın söz varlığı üzerine ilk ciddi çalışma J. Eckmann tarafından hazırlanmış olup $^{12}$ bu çalışmanın tenkiti S. Tezcan tarafından yapılmıştır. ${ }^{13} \mathrm{~J}$. Eckmann'dan önce nüsha ile Z. V. Togan ve A. İnan da ilgilenmiştir. A. Ata'nın hazırladığı giriş - metin - notlar - dizin bölümlerinden oluşan çalışma, nüsha üzerine en bütüncül ve değerli çalışmadır. Yine A. Ata'nın

\footnotetext{
${ }^{10} \mathrm{Bu}$ eser Türkçeye aktarılmıştır: Ragıb el-İsfahanî, Müfredāt Kur'an Kavramları Sözlüğü, (tercüme: Abdulbaki Güneş-Mehmet Yolcu) Çıra Yayınları, İstanbul, 2012.

Bu esere atıflarımızda Müfredāt kısaltmasını kullanacağız.

${ }^{11} \mathrm{Bu}$ nüsha üzerine belli başlı çalışmalar için $b k$. Osman Fikri Sertkaya, Kur'an Tercümesi (Rylands Nüshası) Yayımı Üzerine Bazı Görüşler, Türk Dilleri Araştırmalanı, 17, 2007, s. 319-334.

12 Janos Eckmann, Middle Turkic Glosses of the Rylands Interlinear Koran Translation, Akademiai Kiado, Budapest, 1976.

${ }^{13}$ bk. Aysu Ata, Karahanlı Türkçesinde Illk Kur'an Tercümesi (Rylands Nüshası, Giriş-Metin-Notlar-Dizin), Türk Dil Kurumu Yayınları, Ankara, 2013, s. XXI-XXIII.
} 
nüsha üzerine çeşitli yazıları bulunmaktadır. O. F. Sertkaya'nın Kur'an tercümeleri üzerine yayınladığı yazılar ise alanda yapılan nadir eleştirel bakışlardandır. ${ }^{14}$

Rylands nüshasında Türkçe - Farsça tercüme ilişkileri hususunda J. Eckmann, Türkçe ve Farsça çevirilerin karşılıklı münasebetinin açık olmadığını, ancak Türkçe çevirinin aslında bir Farsça çeviriye dayandığını ${ }^{15}$, bu Türkçe çevirinin de aslında farklı bir zamanda yapılan Türkçe çevirinin nüshaya istinsahı olduğunu düşünmektedir. ${ }^{16} \mathrm{Z}$. V. Togan ${ }^{17}$, Ş. Tekin ${ }^{18}$ ve A. Ata ise ilk Türkçe Kur'an çevirisinin Farsça çeviri ile birlikte yapıldığı görüşündedir. Ayrıca, A. Ata'ya göre Rylands nüshasının tercümanı İspicablı bir Türk'tür. ${ }^{19}$

A. Ata, Türkçe ve Farsça çevirilerin birbiriyle karşılaştırıldığında bunların birbirinden bağımsız nüshalardan alıntılanarak yapılmadığını bir bildirisinin sonunda bol miktarda örnek vererek göstermektedir. ${ }^{20}$ and s1- = evgend şikesten / 'ahd şikesten [neks / hịns ], arı̀g yād ḳ11- / arı̀glıḳ birle yād ḳıl- = be-pākī yād kerden [tesbīh], aytıḳ ḳın = kelime-i ' azāa [ḳavl] ... vb. pek çok örneği işaret ederek de J. Eckmann'ın “Türkçe çevirinin aslında bir Farsça çeviriye dayandığı görülür” tezindeki haklılık payını yabana atmamaktadır. ${ }^{21}$ Farsça ve Türkçe tercümeler karşılaştırmalı olarak incelendiğinde, tercümeler arasındaki bağlantı -kutsal bir metnin çevirisi oldukları için- normal bir durum olarak değerlendirilebilir. Ancak tercümede öyle örnekler vardır ki bu örnekler doğrudan Farsça tercümenin tercümesi olarak da yorumlanabilir. Kanaatimizde Farsça ve Türkçe tercümede Arapça sözcüğün karşılanma biçiminin birebir aynı olmasının yanında karşılıkların Arapça sözcükle doğrudan alakasının olmamas1 etkili olmuştur.

Biz yazının bundan sonraki bölümlerinde bunun gibi örnekler üzerinde durarak konuyu yeniden tartışmaya açmak istiyoruz. Ancak buna geçmeden evvel hemen belirtmeliyiz ki buradaki örneklerin daha önce L. Johanson'un üzerinde durduğu kopyalama kuramı ile açıklanamayacağını düşünüyoruz. Kurama göre, dilde var olan bir sözcük o dili konuşan

\footnotetext{
${ }^{14}$ bk. Osman Fikri Sertkaya, Makaleler 2 (Seçme Araştırma ve İncelemeler), Çantay Kitabevi, İstanbul, 2013.

${ }^{15}$ Janos Eckmann, Doğu Türkçesinde Bir Kur'an Çevirisi (Rylands Nüshası), TDAY-Belleten, 1967, s. 55.

${ }^{16}$ Janos Eckmann, agm., s. 57-58.

${ }^{17}$ Z. V. Togan, The Earliest Translation of the Qor'an into Turkish, Íslam Tedkikleri Enstitüsü Dergisi IV, İstanbul, 1964, s. 134-140.

${ }^{18}$ Şinasi Tekin, Eski Türk Yazı Dillerinin Özellikleri Üzerine Düşünceler ve Bunların Teşekkülü ile Türk Siyasi Birlikleri Arasındaki İliş̧kiler, İștikakçının Köşesi, Simurg Yayınları, İstanbul, 2001, s. 130-131.

${ }^{19}$ Aysu Ata, age., s. XXVI.

${ }^{20}$ Aysu Ata, Rylands Nüshası Kur'an Çevirisi ve Farsça Çevirinin Önemi, V. Uluslararası Türk Dili Kurultayı Bildirileri I, Ankara, 2004, s. 221-230.

Bildiri haricinde bu örneklerin toplu hâli Aysu Ata, age., s. XVII'de de vardır.

${ }^{21}$ Aysu Ata, age., s. XVIII.
} 
milletin yeni bir muhite girmesi neticesinde bu muhitte karşılaşılan yeni kavramların anlamlarını üzerine alabilir. Yani sözcük, bir çeşit anlam değişmesine uğrar ve bu anlam değişmesi genellikle genişleme yönünde olur ${ }^{22}$. Konu üzerine Süer Eker’in örneği yerindedir: iḍ̣ sözcüğüne İslami bir terim olarak "Tanrı" anlamının Karahanlıca döneminde Arapça veya Farsçadan (KB iḍi “1. sahip, 2. Tanrı”) kopyalandığını düşünebiliriz (krş. Ar. rabbu'l-beyt = Far. xa:ne-xoda: = OT eb iḍisi "ev sahibi”) ${ }^{23}$ Kur'an tercümelerine bu yönüyle bakarsak pek çok sözcüğün kopyalama yoluyla anlam değişmesine uğradığı sonucu çıkar, bu da oldukça doğaldır, zira Türkler yeni bir muhite girmiştir ve kavramların bir şekilde karşılanması gerekmektedir. Bizim üzerinde duracağımız mesele ise daha çok kaynak metin - Farsça tercüme metin - Türkçe tercüme metin arasındaki tercüme ilişkileridir.

\section{1. hayż çöpreki (19. sure (Meryem) 23. ayet):}

Bu sözcük, Meryem suresinin 23. ayetinde $A r$. nesy “unutulmak” sözcügünün karş1lığ1 olarak kullanılmıştır ${ }^{24}$.

Sözcük üzerine A. Ata tarafindan ḩayż çöpreki "aybaşı paçavrası” (Ar. nesy “unutul-, Far. rugūy-i hạaż”); Ey kāşski men ölsem munda burun, bolsam hayż çöpreki, unutılmış 31/9b3=19:23. hayż çöpreki: MTGR 128 hayż çüpreki açıklamaları verilmiştir. ${ }^{25}$

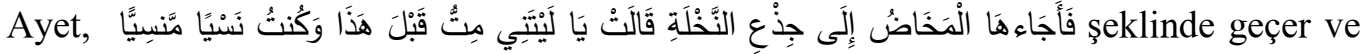
kelimelerin anlamları şöyledir:
1. fe
: böylece, sonra
2. ecāe-hā
: onu mecbur etti

\footnotetext{
${ }^{22}$ Lars Johanson, Code-Copying in Irano-Turkic, Language Sciences 20, s. 325-337.

${ }^{23}$ Süer Eker, Türkçe-Farsça Dil İlişkilerinde Anlam Kopyaları Üzerine Notlar, Sosyoloji Yazıları 1, Hacettepe Üniversitesi Yayınlar1, 2010, s. 199.

${ }^{24}$ Aynı ayet TIEM 73 'te kayıtlı tercümede, ay kāşkī män ölsä ärdim munda öndün bolmış ärse ärdim çıkaru unutmış şeklinde tercüme edilmiştir. çıḳaru unutmış Kök tarafından dizine madde başı olarak alınmamış, sözcük üzerine herhangi bir açıklama getirilmemiştir. çıkaru unut- ya da çıkaru sözcüğünün ne anlama geldiği bilinmemektedir. Sözcügün yanlış okunmuş olabileceğini düşünüyoruz, zira aynı kavram Gülden Sağol'un çalışmasında açıklanmıştır: ay, kāş̧ki men ölse irdim, mundın aşnu; taķı bolsa irdim hor nirse, unutulmış şeklinde tercüme edilen metinde Sağol, hor nirse sözcügüüü dizinde madde başı yapıp "değersiz, hakir şey" olarak anlamlandırmıştır. Bu bilgilerden hareketle sözcüğ̈̈n çıkaru değil ḥakīir ( حاقير ) ve unutmış şeklinde okunabileceğini söyleyebiliriz.

bk. A. Kök, Karahanlı Türkçesi Satır-Arası Kur'an Tercümesi (TiEM 73 1v-235v/2) Giriş-İnceleme-Metin-Dizin, Ankara Üniversitesi Sosyal Bilimler Enstitüsü Türk Dili ve Edebiyatı Anabilim Dalı Eski Türk Dili Bilim Dalı, (yayınlanmamış doktora tezi), Ankara, 2004, s. 221-346.

bk. Gülden Sağol, Harezm Türkçesi Satır Arası Kur'an Tercümesi Giriș-Metin-Sözlük, Marmara Üniversitesi Türkiyat Araştırmaları Enstitüsü Türk Dili ve Edebiyatı Bölümü Türk Dili Anabilim Dalı, (doktora tezi), İstanbul, 1993, s. 221, 346.

${ }^{25}$ Aysu Ata, age., s. 374; 183.
} 
3. el-mehāżū

: doğum sancisı

4. ilā cižı'n-nahleti : hurma ağacının gövdesine

5. ḳālet

: dedi (o)

6. yā leyte-nī

: keşke (ben) olsaydım

7. mittu

: öldü(m)

8. kable

: önce

9. hazā

: bu

10. ve kuntu

: ve (ben) oldum

11. nesyen

: unutularak

12. mensiyyen

: unutulan

13. nesyen mensiyyen : tamamen unutulmuş ${ }^{26}$

Görüleceği üzere $A r$. nesy "unutulmak" sözcüğünün karş1lığ1 olarak verilen ḥayż çöpreki “aybaşı paçavrası” sözcügünün Kur'an'da geçen herhangi bir sözcükle doğrudan alakası yoktur. Ancak, nesy sözcügünün Farsça karşıllı̆ı olarak metinde rugūy-i ḥayż şeklinde bir tamlama kullanılmıştır. rogū, rigū Farsça bir sözcük olup "yıpranmış giysi” anlamındadır. ḩayż ise Arapça bir sözcüktür ve "regl, adet görme, aybaşı hâli” olarak anlamlandırılır. ${ }^{27}$

Sonuç olarak Ar. nesy sözcüğü -belki de kuvvetli bir anlatım için- Farsçaya rugūy-i ḥayż şeklinde çevrilmiştir. Metnin Türkçeye tercümesinde ise açıkça bahsi geçen tamlamanın çevirisi söz konusudur. Yani kaynak olarak Arapça metin değil Farsça metin esas alınmıştır. ${ }^{28}$

\footnotetext{
${ }^{26}$ Müfredat, s. 1053-1055.

Müfredat'ta verilen bilgiye göre sözcükle ilgili açıklama şöyle başlar: unutmak anlamına gelir... İlgili ayette ise nesyen sözcüğü "unutulmasa da hiçbir değeri olmayan bir ev eşyası gibi olmak" anlamına gelir. Tabii burada verilen bilgi tefsirî bir bilgidir. Buradan hareketle Farsçaya yapılan tercümede tefsir usulüne başvurulduğu sonucu çıkar.

${ }^{27}$ Mehmet Kanar, Farsça Türkçe Sözlük, Say Yayınları, Ankara, 2010, s. 778-630.

${ }^{28}$ Tam zıttı şeklinde bir görüş belirebilir, yani bu tercümenin önce Türkçeye ardından da Türkçeden Farsçaya yapılmış olabileceği. Bu pek mümkün görünmemektedir. Çünkü bilinen en eski Kur'an tercümeleri Farsçadır. Bölgede de Farsçanın yoğun şekilde konuşulduğuna dair kayıtlar vardır. Bölgede 100 yıldan fazla süren Samani egemenliği de unutulmamalıdır. Ayrıca nüshada tercüme sıralaması Farsça - Türkçedir. Sıralama olmayan nüshalardan biri olan Özbekistan nüshası için bu durum düşünülebilir. Özbekistan nüshasında Farsça - Türkçe sıralama yerine çapraz şekilde tercüme sıralaması vardır. Ancak onda bile tercümenin să̆ kısmının Farsça sol kısmının Türkçe olması düşündürücüdür.
} 


\section{2. yelinigli tamug (34. sure (Sebe') 12. ayet):}

Bu sözcük, Sebe' suresinin 12. ayetinde $A r$. sa'îr "ateş" sözcüğünün karş1llğı olarak ... yarlıġmızdın taturgay-miz angar, ol yelinigli tamug ḳınıdın cümlesinde kullanılmıştır. ${ }^{29}$

A. Ata, sözcüğün yelin- fiili üzerine -(i)gli sıfat-fiil eki ile oluştuğunu ve fiil kısmının yalın- ile aynı olduğunu söylemektedir: yalın hem fiil hem de isim köküdür. Clauson "flame" anlamını verdiği yalın isminin kökünü yal- olarak olarak vermiştir. Fakat Altay ve Teleüt Türkçelerinden tanıklar verdiği yalın- "to flash" için ise kök kelimeyi *yal- şeklinde göstermiştir. Hâlbuki KB III 517 yal- "parlamak", yalın "alev", yalın- "yanmak" bir arada geçmektedir. Tezcan, KB' deki yalın- fiilinin "parlamak” şeklinde düzeltilmesini önermektedir. ${ }^{30}$ Kısacası, yalın- / yelin- "parlamak" demektir.

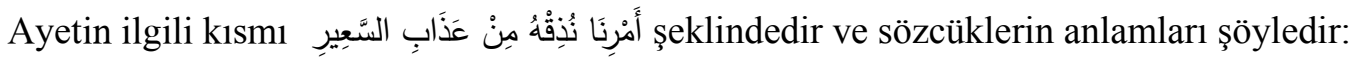

1. an-emri-nā : emrimizden

2. nuzık-hu : ona tattırırız

3. $\min :$ den

4. azāa : azap

5. es-sa'ir $\quad$ : ateş

Ar. sa'īir "ateş" sözcüğü azāāb sözcüğünün ḳın ile karş1landığı gibi ot "ateş" veya küyürküyürgen "yanmak, yakan” gibi sözcüklerle karşllanabilirdi ${ }^{31}$, ancak yelinigli tamuǵg gibi bir sıfat tamlamasına başvurulması ancak $A r$. sa'îr "ateş" sözcüğünün Farsça çevirisinin āteş-i furūzān şeklinde yapılması ile açıklanabilir. furūzān bilindiği üzere "parlatan, ışı veren, aydınlatan, yakan, yanan" anlamlarındadır ${ }^{32}$.

\footnotetext{
${ }^{29}$ Aysu Ata, age., s. 33.

${ }^{30}$ Aysu Ata, age., s. 185.

${ }^{31}$ TİEM 73'te kayıtlı tercümede küyürgän ile Harezm Türkçesi Kur'an Tercümesinde ise tamuǵ ile karşılanmıştır. bk. Suat Ünlü, Karahanlı Türkçesi Satır-Arası Kur'an Tercümesi (TİEM 73 235v/3-450r 7) Giriş -Metin-İncelemeAnalitik Dizin, Hacettepe Üniversitesi Sosyal Bilimler Enstitüsü Türk Dili ve Edebiyatı Anabilim Dalı Eski Türk Dili Bilim Dalı, (yayınlanmamış doktora tezi), Ankara, 2004, s. 131.

bk. Gülden Sağol, age., s. 323.

${ }^{32}$ Mehmet Kanar, age., s. 1123.

TİEM 73'te kayıtlı tercümede de aynı şekilde tercüme edilmiştir. TİEM 73'teki tercümenin bu kısmı Rylands nüshası ile neredeyse birebir aynıdır. Harezm Türkçesi Kur'an tercümesinde ise bu ayet eksiktir.

bk. A. Kök, age., s. 192.

bk. Gülden Sağol, age., s. 193-194.
} 
Görüldüğü üzere burada da yelinigli tamug "kor ateşli cehennem" tamlamasına kaynaklık edecek bir sözcük veya tamlama, kaynak metin Kur'an'da bulunmamaktadır. Çevirinin bu şekilde yapılması ancak Farsça tercümeden etkilenme veya Farsça tercümenin esas alınması ile açıklanabilir.

\section{3. bekümiş tag (16. sure (Nahl) 15. ayet):}

Sözcük, Nahl suresinin 15. ayetinde Ar. revāsi sözcüğünün karşıllı̆ı olarak kemiştiler yer içinde bekümiş tag̉lar tā yoḳatmasun sizlerni cümlesinde kullanılmıştır. ${ }^{33}$ Sözcük Ata tarafından "sabit ve gösterişli dağ" şeklinde anlamlandırılmıştır. ${ }^{34}$

Ayetin ilgili bölümü وَأَلَقَى فِي الأَرْضِ رَوَابِيَيَ şeklindedir ve ayette geçen sözcükler şu şekilde anlamlandırılabilir:

1. ve elḳā : ve biraktı, koydu, attı

2. fỉ el-arḍı $\quad$ : yeryüzünde

3. revāsi(ye) : dağlar?

Arapça sözcük aslında "sabit olmak" anlamına gelmektedir. resā eş-şeyyi yers $\bar{u}$ "şey sabit oldu" ersāhu gayruhu "onu başkası sabitleştirdi". r-s-v kökünden türeyen sözcük, Sebe' suresi 13. ayette şöyle geçer: ḳudūrin rāsiyātin "sabit, yerinden oynamayan büyük kazanlar". Naziāt suresinin 32. ayetinde ve'l-cibāle ersā-hā "dağları oturttu (sabit kıldı). ${ }^{35}$ Son örnekte görüleceği üzere “dağ” sözcüğü Kur’an'da cibāl / cebel ile karşılanır ve sıkça kullanılır. ${ }^{36}$ rāsíc ve revā̄si sözcükleri ise r-s-v kökünden türemiş aslında "sabit olmak, sabit olan şey" anlamına gelen bir sözcüktür. Sözcüğün "dağ" anlamı tefsirlerden kaynaklanır. Zira dăg, "yerinden oynatılamayacak şey”dir. Kısacası çeviride bekümiş sıfatına kaynaklık edecek bir sözcükten söz

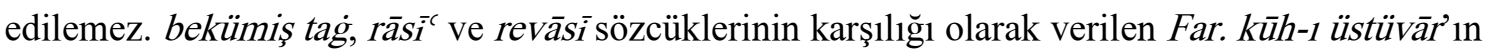
çevirisidir. ${ }^{37}$

\section{4. belgülüg hüiccet (35. sure (Fātır’) 40. ayet):}

“Açık delil, kanıt, basiret” anlamlarına gelen sözcük Ar. bașīet sözcüğünün karş1lı̆̆ olarak Fātır' suresinin 40. ayetinde olar belgülüg hüccet üze tururlar cümlesinde

\footnotetext{
${ }^{33}$ Aysu Ata, age., 50.

${ }^{34}$ Aysu Ata, age., 255.

${ }^{35}$ Müfredat, $s .428$.

${ }^{36}$ bk. Şaban Kurt, Kur'an-1 Kerim Sözlerini Bulma Kılavuzu, Çağrı Yayınları, İstanbul, 2009, s. 112-113.

${ }^{37}$ üstüvār bilindiği üzere "sağlam, muhkem, dayanıklı" demektir.
} 
kayıtlanmıştır. ${ }^{38}$ Ar. bașiret sözcügüünün Farsça karşıllğı olarak ise hü̈ccet, hü̈ccet-i rūşsen ve hā-i peydā kullanılmıştır. Kavram, belgülüg belgü ile karşılanabilirdi, zira tercümenin 28/5a1 ve 27/41b1 varaklarında aynı kavram bahsi geçen şekilde karşılanmıştır ${ }^{39}$ :

Hakikat kim aymamaḳım üze Tangrı üze meger rāstnı yaraġlıg bütünlükin keldürdüm sizke belgülüg belgü birle İdingizdin ... (28/4b1, 5a1= 7:105).

Keldi olarka yalavaçları belgülüg belgüler birle (29/50b1=9:70).

Sonuç olarak Ar. bașiret sözcüğü Türkçe ile karşılanabilirken Farsça çeviriden etkilenerek belgülüg belgü yerine belgülüg hüccet kullanılmıştır.

\section{5. hemiş̧e ya' nī ulaşu (33. sure (Ahzāb) 53. ayet):}

$\mathrm{Bu}$ sözcük 33. surenin (Ahzāb) 53. ayetinde ebeden sözcügünün karşıllğı olarak geçmektedir ${ }^{40}$ :

hemişse ya'nī ulaşu ol erür Tangrı üskinde ulug

Ayetin ilgili bölümü ve ayetteki kelimelerin anlamları şöyledir:

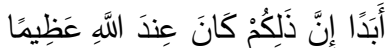

1. ebeden : ebediyyen

2. inne : muhakkak

3. zalikum : bu

4. kāne : oldu

5. 'indallāhi (inde allāhi) : Allah'ın katında

6. 'az̧ìmen : büyük

ebeden sözcüğü metinde sadece ulaşu ile karşılanabilmektedir:

Tevbe suresinin 22. ayeti:

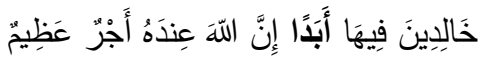

Cāvidāneler anıng içinde ulaşu 29/16a2=9:22

\footnotetext{
${ }^{38}$ Aysu Ata, age., s. 257.

${ }^{39}$ Aysu Ata, age., s. 257.

${ }^{40}$ Aysu Ata, age., s. 81.
} 
Tevbe suresinin 84. ayeti:

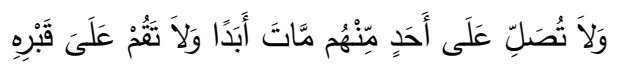

namāz ḳılmaġıl kimerseke olardın öldi ulaşu aḍaḳın turmag̉ıl anıng gūrı üze $29 / 60 \mathrm{a} 3=9: 84^{41}$

Yukarıda görüldüğü gibi ebeden sözcüğü Türkçe ile karş1lanabilmektedir. Ancak Ahzāb suresinin 53. ayetinin tercümesi hemişse ya'nī ulaşu ol erür Tangrı üskinde ulug şeklinde yapılmıştır. hemişse ve ulaşu sözcükleri aynı anlama gelen biri Farsça diğeri Türkçe iki sözcüktür. Tercümeyi yapan ebeden sözcüğünün altında yazan hemişe sözcüğünü önce yine hemişse ile daha sonra ya'nī diyerek ulaşu ile karşılamıştır. Yani bir çeşit ikileme oluşturmuştur. Kısacas1, hemişse sözcüğüne Türkçe tercümede aslında gerek yoktur.

\section{6. būstān (9. sure (Tevbe) 72. ayet):}

Rylands nüshasında Ar. cennet sözcügünün karşıllğı olarak çoğunlukla uçtmaḥ / uştmaḥ kullanılmıştır:

48. sure (Feth) 5. ayet ${ }^{42}$ :

kigürgü üçün mü` minlerni hem mü‘ minlerni uçtmaḥlarḳa aḳar astnıda arıḳlar

4. sure (Nisā) 57. ayet ${ }^{43}$ :

...munu kügrür-miz olarnı uştmaḥlarḳa kim ...

20. sure (Tāhā) 121. ayet ${ }^{44}$ :

...yapışturu āgāāzladılar ol iki üze uştmaḥ yapraḳındın ...

9. sure (Tevbe) 72. ayette ise cennet sözcügü Far. būstān sözcüğü ile karşılanmış, cennet sözcüğünün karşıllı̆̆ olarak cennet hiç kullanılmamıştır ${ }^{45}$ :

mü` min urag̉utlarḳa būstānlar kim aḳar ...

$\mathrm{Bu}$ durum da tercümeyi yapanın Farsça tercümeden etkilenmesi ile açıklanabilir, zira cennāt-1 'adn “adn cennetleri” Farsçaya būstānhā-yı bāşìden şeklinde çevrilmiştir. bāşsìden

\footnotetext{
${ }^{41}$ Aysu Ata, age., s. 706.

${ }^{42}$ Aysu Ata, age., s. 136.

${ }^{43}$ Aysu Ata, age., s. 10.

${ }^{44}$ Aysu Ata, age., s. 72.

${ }^{45}$ Aysu Ata, age., s. 42.
} 
“olmak, kalmak, konaklamak" demektir. ${ }^{46}$ 'adn sözcüğü ile ilgili Müfredat'ta şu bilgiler kayıtlıdır: adn cennetleri, yani istikrar ve sebat cennetleri. 'aden bi-mekān-ı kez̄ā falan yerde karar kıldı. Maden yatakları anlamındaki ma'den kelimesi de bu anlamdan gelmektedir. ${ }^{47}$ Görüşümüzü çevirilerin karşıllaştırılması destekleyecektir:

\begin{tabular}{ccc}
\hline & cennāt-1 ' adn & \\
\hline 9. sure (Tevbe) 72. ayet & turğu būstānlar & būstānhā-yı bāşīiden \\
\hline 19. sure (Meryem) 61. ayet & turğu būstānlar & būstānhā-yı bāşīiden \\
\hline 20. sure (Enbiyā) 76. ayet & ulaşu turğu būstānlar & būstānhā-yı peyveste būden \\
\hline
\end{tabular}

cennāt-1 'adn "istikrar ve sebat cennetleri" "sürekli meskun olunacak yer" anlamındadır.

Tabloda görüldüğü üzere Enbiyā suresinin 76. ayetinde cennāt-1 'adn, ulaşu turğu būstānlar ile karşılanmıştır. Burada çeviriye elbette bir eleştiri getirilemez, çünkü ulaşu turğu būstānlar, kavramı tam olarak karşılamaktadır. Peki neden sadece Enbiyā suresinin 76. ayetinde böyle bir tercüme yapılmıştır? Tevbe ve Meryem surelerinin tercümelerinde aynı kavram neden ulaşu turğu būstānlar ile ya da Enbiyā suresinin tercümesinde kavram neden turğu būstānlar ile karşılanmamıştır? Farsça tercüme ile Türkçe tercüme arasında çok ciddi benzerlik vardır (ulaşu turg் $=$ peyveste būden; būstān $=$ būstān) .

$\mathrm{Bu}$ yazıda sadece 6 örnek üzerinde duruldu. ${ }^{48} \mathrm{Bu} 6$ örnek belli bir gruplandırmaya göre seçildi. 1, 2, ve 3. örnekler Farsça tercümenin doğrudan Türkçeye tercümesine; 4 ve 5. örnekler Farsça tercümeden etkilenme olarak değerlendirilebilecek sözcüklere örnektir. 6. örnek ise Farsçaya iki sözcükle tercüme edilen sözcüklerin Türkçeye iki, üç sözcükle tercüme edilen sözcüklerin üç sözcükle karşılanması gibi tercümede sayıca denk olan örneklerden biridir.

Bunun gibi örnekler, Özbekistan nüshasında az sayıdadır. Farsçaya iki, üç, dört sözcük ile tercüme edilen sözcüklerin Türkçeye bir veya iki sözcükle tercüme edildiği çok sık görülür. Farsça tercümenin zaman zaman tefsir usulüne kaçtığı da görülebilmektedir. Mesela furkāann sözcüğü Türkçeye ayırt kemişgen ile tercüme edilirken Farsçaya nușret-i cüdā konend-i miyān-1 hakk u bāțll şeklinde tercüme edilmiştir. Özbekistan nüshasında, Farsça tercüme ile Türkçe tercüme arasında kesin bir bağlantı görülmemektedir. Taradığımız örnekler incelenirse durum rahatça anlaşı1labilir ${ }^{49}$ :

āmm: ug̉ag̉an, ḳaṣd konende [268a]/5 = M:2; aṣhāābi'l-caḥimm: tamug eyeleri, yārān-1 āteş-i buzurg [29b]/3 =B:19; ' avž: āyāt, nişānhā [9b]/1 = B:41; bāsiṭ: yay-, derāz kerden

\footnotetext{
${ }^{46}$ Mehmet Kanar, age., s. 264

${ }^{47}$ Müfredat, s. 682.

${ }^{48}$ Aysu Ata'nın işaret ettiği diğer örnekler için bk:: Aysu Ata, age., s. XVIII-XX; Aysu Ata, agm., s. 230.

${ }^{49}$ İlk sözcük Kur'an'daki sözcük, ikinci sözcük Türkçeye tercüme edilen sözcük, virgülden sonraki yani üçüncü sözcük Farsçaya tercüme edilen sözcüktür.
} 
[210b]3 = M:28; beġżāa $:$ yigrenmek, düşmānī-yi nihān [198b]/1 = M:64, [253b]/4 = M:14; beșs: yay-, perāgende kerden [144a]/2 = N:1, [43a]/1 =B:164; cahịm: tamug, āteş-i buzurg [29b]/3 = B:119; cāriḥ: kesb ḳ1lgan, murganan u segān-1 şikār [248a]/5 = M:4; cezā: öte-, kifāyet kerden [10b]/2 = B:48; ebrāṣ: ala tenlig, pīs [104a]/1 = A:49; edā: ötemek, güzārde şoden [47b]/5 = B:178; ednā: ḳadrsızrak, nezdīkter ya'ni kemter [14b]/3 = B:61; el-ḳayyūm: peyveste örelik ḳ1 ġan, pāyende $[77 \mathrm{~b}] / 5=\mathrm{B}: 255,[91 \mathrm{a}] / 2=\mathrm{A}: 2$; el-vāsic $:$ king, tevānger ferāhkār $[81 \mathrm{~b}] / 4=$ B:261; er-ra' ūf: ḳulluḳ ḳ1-, ' ibādet [104b]/2 = A:51; er-ra' ūf: raḥmet ḳ1lgan, mihrbān [99a]/4 = A:30; mülk: erklenmek, tașarruf şoden [144b]/5 = N:3; ez̄ā: naḥoş kelgen nerse, āzār [64a]/3 = B:222; furḳān: ayırt kemişgen, nuṣret-i cüdā konend-i miyān-1 hạk u bạṭ̣l [11b]/4 = B:53; galebet: yingil-, galebe kerde şoden [93b]/3 = A:12; ḥacc: ḥacc, ziyaret kerden-i ḩāne [52a]/1 = B:189; haşr: yı̀g-, zūd būd gird kerden [265b]/4 = N:172; hevā: hevā, ārzū-yı dileva [30a]/1 = B:120; iflāh: ḳurtul-, restegārī yāften [117b]/4 = A:104; inẓār: küyül-, zamān dāde şoden [113b]/4 = A:88; ic timār: ziyāret ḳ1l-, ' umre āmeden [41a]/4 = B:158; ittibā' m: uyul-, pesresvī kerde şoden [43b]/4 = B:166; ḳıșạṣ: tüzlük ḳılışmaḳ, berāber [217a]/3 = M:45; kiber: ulug̉luḳ, buzurg-1 sāli [101b]/3 = A:40; maşrıḳ: maşrık, cāy-1 ber āmeden āftāb [28b]/2 =B:115; sıbg̉at'allāh: artmaḳ, nigāh dāşten-dīn-i hudāy [35a]/4 = B:138. ${ }^{50}$

Demek ki bu durum, Rylands nüshasında daha çok karşımıza çıkmaktadır. Farsça Türkçe tercüme ilişkisinin Rylands nüshasında daha net görülmesinde nüshanın şu ana kadar bilinen en eski Türkçe Kur'an tercümesi olmasının mutlaka bir payı olmalıdır.

\section{Sonuç:}

1. Tercüme iki dili de (Farsça ve Karahanlı Türkçesi) bilen bir kişi tarafından aynı veya yakın zamanda yapılmış olmalıdır. Bölgede, geçmişi çok eskilere dayanan Soğd - Fars - Türk ilişkileri Kur'an'ın tercüme meselesinde etkisini göstermiş, Farsça tercüme (ya da tercümeler) Kur'an'ın Türkçeye tercümesinde model olmuştur. Buradaki model ile çevirinin nasıl yapılacağını değil, çevirinin bizzat kendisini kastediyoruz. Yani Türkçe tercümenin Farsça tercümenin tercümesi olması kuvvetle muhtemeldir.

2. Tercümeyi yapan şahsın Türk olduğunu iddia etmek yerine iki dilli biri tarafından yapıldığını söylemek daha makuldür. Çünkü bölgede Farslar ve Türkler iç içedir. Bu iç içelik mezhep birliğinde de görülür. Bugün aynı bölgede yaşayan Taciklerin büyük çoğunluğunun

\footnotetext{
${ }^{50}$ Emek Üşenmez, Türkçe IIlk Kur'an Tercümelerinden Özbekistan Nüshası, Eskişehir Valiliği Yayınları, Eskişehir, 2013.
} 
sünni ve dillerinin Türkçeden yoğun şekilde etkilenmiş olması bunun delilidir. Tercümenin yapıldığg dönemde, yönetim kademesinde bulanan ya da bulunmayan Fars asıllı birinin Türkçe bilmesi olağanüstü bir şey değildir.

Kaşgarlının Soğd / Soğdak sözcüğüne verdiği anlamı burada paylaşmak yerinde olacaktır:

Buhara ve Semerkant arasındaki Soğd bölgesinden olan, Balasagun'a konan, Türkler gibi giyinip onların huylarını alan iki dilli bir kavim. ${ }^{51} \mathrm{Bu}$ iki dilin Farsça - Türkçe olduğu aşikârdır.

3. Meselenin burada verilen örneklerle çözülemeyeceği çok açıktır. Çünkü burada verilenlerin tam tersi örnekler de vardır. Mesela $A r$. 'arşs sözcüğü Farsçaya taht-ı buzurg şeklinde tercüme edilirken Türkçeye $A r$. 'arş ile tercüme edilmiştir ${ }^{52}$. Ancak bu örnekler yukarıdaki örneklerin benzerlerine nazaran oldukça azdır. Ayrıca böyle örneklerin pek çoğunu Türkçe tercümedeki Arapça asıllı sözcükler oluşturmaktadır. Türkçe tercümede kullanılan bazı Arapça sözcüklerin Farsçaya geçtikleri hâlleriyle kullanılması da düşündürücüdür. Mesela, $A r$. 'arż "sunma, sunuş" sözcüğü Türkçe tercümede Farsçaya geçtiği şekliyle ('arża) yer almaktadır. ${ }^{53}$

Rylands nüshasında, Farsça tercümenin Türkçe tercüme ile çeşitli açılardan ilişkili olduğu kesindir, ancak bahsi geçen diğer hususların eldeki veriler dâhilinde ihtimal ve çıkarımlardan öteye geçemeyeceği unutulmamalıdır.

Yapılması gereken Kur'an'ın Farsçaya yapılan en eski tercümelerini de Arapça - Farsça - Türkçe tercümelerin Farsçasıyla söz varlığı açısından karşılaştırmaktır. ${ }^{54}$ Böylece Kur'an'ın Türkçeye tercümesi meselesinde tercüme için ana kaynağın mı yoksa Farsça tercümelerin mi kullanıldığı ortaya çıkacaktır. Bu işe başlamadan evvel de Doğu Türkçesiyle yazılmış satırarası Kur'an tercümelerinin karşılaştırmalı olarak incelenmesi elzem durmaktadır.

\footnotetext{
${ }^{51}$ DLT, s. 826.

${ }^{52}$ bk. Aysu Ata, age., s. 225.

${ }^{53}$ bk. Aysu Ata, age., s. 228.

${ }^{54}$ Farsça tercümelerin karşılaştırmalı metin yayını hâlihazırda mevcuttur: H. Yagmaî, Terceme-i Tefsir-i Taberi . $b k$. Aysu Ata, age., s. XIII.
} 


\section{Kisaltmalar}

A: Āl-i İmran Suresi

$A r$ : Arapça

B: Bakara Suresi

E: En`ām Suresi

Far. :Farsça

DLT: Divanu Lugati't-Türk

KB: Kutadgu Bilig

M: Māide Suresi

N: Nisa Suresi.

\section{Kaynaklar}

Alyılmaz, C. (2003). Bugut yazıtı ve anıt mezar külliyesi üzerine. Türkiyat Araştırmaları Dergisi, 13, 11-21.

Ata, A. (2004). Rylands nüshası Kur'an çevirisi ve Farsça çevirinin önemi. V. Uluslararası Türk Dili Kurultayı Bildirileri I, Ankara, 221-230.

Ata, A. (2013). Karahanlı Türkçesinde ilk Kur'an tercümesi (Rylands Nüshası, Giriş-MetinNotlar-Dizin). Ankara: Türk Dil Kurumu Yayınları.

Barthold, V. V. (2011). Orta Asya Türk tarihi. Ankara: Divan Kitap.

Doerfer, G. (1967). Türkische und Mongolische elemente im neupersischen. Wiesbaden.

Eckmann, J. (1967). Doğu Türkçesinde bir Kur'an çevirisi (Rylands nüshası). TDAY-Belleten, 51-69.

Eckmann, J. (1976). Middle Turkic glosses of the Rylands interlinear Koran translation. Budapest: Akademiai Kiado.

Eker, S. (2009). Divanü Lügati't-Türk ve İran dillerinden kopyalar üzerine. I. International Journal of Central Asian Studies, 13, 233-283. 
Eker, S. (2009). Türk-İran dil ilişkilerinde Divanü Lügati’t-Türk tanıklığı. Akademik Araştırmalar Dergisi, 39, 70-85.

Eker, S. (2010). Orhon Yazıtları: İran dilleri ile ilk temaslar ve benzer birkaç öge üzerine. III. Uluslararası Türkiyat Araştırmaları Sempozyumu, C1, 321-332.

Eker, S. (2010). Türkçe-Farsça dil ilişkilerinde anlam kopyaları üzerine notlar. Sosyoloji Yazıları 1, Hacettepe Üniversitesi Yayınları, 197-211.

Eker, S. (2012). Orta Asya'nın gizemli halkı: Soğdlular Soğd ve Soğdca. Türkbilig, 2012/24, 77-92.

Ercilasun, A. B. ve Akkoyunlu, Z. (2014). Divanu Lugati’t-Türk. Ankara: Türk Dil Kurumu Yayınları.

Johanson, L. (1998). Code-copying in Irano-Turkic. Language Sciences, 20, 325-337.

Kanar, Mehmet (2010). Farsça Türkçe sözlük. Ankara: Say Yayınları.

Karakaş, S. (2010). Türk tarihinde Maniheizm (VIII.-XIII. yüzyıllar). Yayımlanmamış doktora tezi, Ankara: Hacettepe Üniversitesi Sosyal Bilimler Enstitüsü.

Kök, A. (2004). Karahanlı Türkçesi satır-arası Kur'an tercümesi (TIEM 73 1v-235V/2) GirişInceleme-Metin-Dizin. Yayımlanmamış doktora tezi, Ankara: Ankara Üniversitesi Sosyal Bilimler Enstitüsü.

Kurt, Ş. (2009). Kur’an-ı Kerim sözlerini bulma kılavuzu. İstanbul: Çağrı Yayınları.

Mackerras, C. (2009). Uygurlar. Erken İç Asya tarihi, İstanbul: İletişim Yayınları, 425-449.

Narain, A. K. (2009). İç Asya'da Hint-Avrupalılar. Erken İç Asya tarihi, İstanbul: İletişim Yayınları, 209-244.

Ragıb el-İsfahanî (2012). Müfredāt Kur'an kavramları sözlügü. (Tercüme: Abdulbaki Güneş Mehmet Yolcu). İstanbul: Çıra Yayınları.

Roux, J. P. (2008). Türklerin tarihi. İstanbul: Kabalc1 Yayınları.

Sağol, G. (1993). Harezm Türkçesi satır arası Kur'an tercümesi giriş- metin-sözlük. Yayımlanmamış doktora tezi, İstanbul: Marmara Üniversitesi Türkiyat Araştırmaları Enstitüsü. 
Sertkaya, O. F. (2007). Kur'an tercümesi (Rylands nüshası) yayımı üzerine bazı görüşler. Türk Dilleri Araştırmaları, 17, 319-334.

Sertkaya, O. F. (2013). Makaleler 2 (seçme araştırma ve incelemeler). İstanbul: Çantay Kitabevi.

Tekin, Ş. (2001). Eski Türk yazı dillerinin özellikleri üzerine düşünceler ve bunların teşekkülü ile Türk siyasi birlikleri arasındaki ilişkiler. İștikakçının Köşesi, İstanbul: Simurg Yayınları.

Togan, Z. V. (1964). The earliest translation of the Qor'an into Turkish, Íslam Tedkikleri Enstitüsü Dergisi, IV, 134-140.

Togan, Z. V. (1981). Umumî Türk tarihine girişs. İstanbul: Enderun Kitabevi.

Ünlü, S. (2004). Karahanlı Türkçesi satır-arası Kur’an tercümesi (TíEM 73 235v/3-450r 7) Giriş -Metin-İnceleme-Analitik Dizin. Yayımlanmamış doktora tezi, Ankara: Hacettepe Üniversitesi Sosyal Bilimler Enstitüsü.

Üşenmez, E. (2013). Türkçe ilk Kur'an tercümelerinden Özbekistan nüshası. Eskişehir: Eskişehir Valiliği Yayınları. 